\title{
Effect of mangosteen (Garcinia mangostana L.) peel extract as an antibiotic growth promoter on growth performance and antibiotic resistance in broilers
}

\author{
Okti Herawati (D), Tri Untari(D), Marla Anggita (iD and Sidna Artanto \\ Department of Microbiology, Faculty of Veterinary Medicine, Universitas Gadjah Mada, Yogyakarta, Indonesia. \\ Corresponding author: Okti Herawati, e-mail: oktihera@ugm.ac.id \\ Co-authors: TU: t_untari@ugm.ac.id, MA: marla.anggita@ugm.ac.id, SA: adasidna@ugm.ac.id \\ Received: 11-12-2019, Accepted: 17-03-2020, Published online: 27-04-2020
}

doi: www.doi.org/10.14202/vetworld.2020.796-800 How to cite this article: Herawati O, Untari T, Anggita M, Artanto S (2020) Effect of mangosteen (Garcinia mangostana L.) peel extract as an antibiotic growth promoter on growth performance and antibiotic resistance in broilers, Veterinary World, 13(4): 796-800.

\begin{abstract}
Background and Aim: Antibiotic resistance poses a risk to human health and has therefore been the focus of research. One of the causes of this resistance is the use of antibiotics as feed additives for animal nutrition. The development of antibiotic resistance in poultry through nutrition feed has drawn attention to the need for alternative antibiotic growth promoters (AGPs). Mangosteen (Garcinia mangostana L.), as a natural source of bioactive phytochemicals, is a potential AGP, but the effect of mangosteen-based treatment on antibiotic resistance in poultry has not been reported to date. Therefore, the aim of this study was to evaluate the effects of mangosteen peel extract as an AGP on body weight gain, feed conversion rate (FCR), and the antibiotic resistance in broilers.

Materials and Methods: In this study, 30 1-day-old broiler chicks were divided into three groups. Group A (control) was not administered any treatment in the feed, Group B was treated with $0.3 \mathrm{~g} / \mathrm{kg}$ colistin as the AGP in the feed, and Group $\mathrm{C}$ was treated with $2 \%$ mangosteen peel extract as the AGP in the feed; the treatments were administered for 30 days. The observed parameters included the effect of the treatments on body weight gain, feed intake, FCR, and the presentation of antibiotic resistance before and after the treatments (pre-treatment and post-treatment, respectively).

Results: Post-treatment, the body weight gain, and feed intake in the broilers were not significantly different among all the groups; however, the body weight gain and FCR were significantly different between the control group and the treatment groups in the 3rd week of treatment and were not significantly different between Groups B and C. The rate of antibiotic resistance to chloramphenicol increased significantly by $40 \%$ in Group B post-treatment, but no such increase was observed in Groups A and C.

Conclusion: The findings of our study indicate that compared with using colistin as an AGP using mangosteen peel extract as a natural AGP did not have any significantly different effect on body weight gain, feed intake, and FCR ( $p>0.05)$ but had a significantly different effect on the rate of antibiotic resistance in broilers $(p<0.05)$. This study indicates the usefulness of mangosteen for improving the overall growth and production performance of broilers without increasing their antibiotic resistance.
\end{abstract}

Keywords: antibiotic resistance, antibiotics, broiler, growth promoters, mangosteen.

\section{Introduction}

Antibiotic resistance is a serious global concern that has become a major challenge in human and animal research [1]. In the USA, bacterial strains with antibiotic resistance reportedly account for at least 2 million infection cases and 23,000 human deaths every year [2]. Antibiotic resistance has also been reported in Indonesia; the 2012 surveillance data obtained from the Ministry of Health reports showed that the prevalence rate of extended-spectrum $\beta$-lactamase-producing Escherichia coli had increased to $52 \%$ in Indonesia [3].

Copyright: Herawati, et al. Open Access. This article is distributed under the terms of the Creative Commons Attribution 4.0 International License (http://creativecommons.org/licenses/ by/4.0/), which permits unrestricted use, distribution, and reproduction in any medium, provided you give appropriate credit to the original author(s) and the source, provide a link to the Creative Commons license, and indicate if changes were made. The Creative Commons Public Domain Dedication waiver (http:// creativecommons.org/publicdomain/zero/1.0/) applies to the data made available in this article, unless otherwise stated.
Antibiotic resistance is caused by various factors such as the excessive empirical administration of antibiotics in clinical practice, failure to complete the antibiotic dose as per the regimen, the indiscriminate use of antimicrobials in agriculture, and the rate and duration of using the antimicrobial therapy [4]. In the agricultural sector, particularly in the poultry industry, antibiotics have been used as feed additives to treat and prevent infections or to improve the growth and production performance of chickens [5].

Based on the data of the application of antibiotic growth promoters (AGPs) in animal production consist neomycin, erythromycin, oxytetracycline, streptomycin and colistin, particularly in chicken production, the global consumption of antimicrobials has been predicted to increase by $67 \%$ between 2010 and 2030 [6]. The increased use of AGPs in chickens potentially imposes an elevated selection pressure on bacteria to become resistant to antimicrobials $[5,6]$. 
The development of antibiotic resistance in chickens has drawn attention to the need for alternative AGPs. AGPs from natural sources could play a key role in improving the growth and production performance of chickens. One of the natural plant sources that can be used as AGPs is mangosteen (Garcinia mangostana L.) peel, which comprises bioactive phytochemicals such as xanthones, benzophenones, flavonoids, bioflavonoids, phenols, and triterpenes $[7,8]$. These bioactive phytochemicals function as an antibiotic and reportedly improve the growth and production performance of broilers, indicating the potential use of mangosteen as an AGP $[9,10]$. However, to the best of our knowledge, no study to date has elucidated the effect of using mangosteen peel as an AGP on the antibiotic resistance developed in broilers.

Therefore, the present study aimed to evaluate the effect of using mangosteen peel as an AGP in broiler feed on body weight gain, feed conversion rate (FCR), feed intake, and antibiotic resistance in broilers.

\section{Materials and Methods \\ Ethical approval}

All experiments of this research study were approved by the ethical committee of our institution (reference number: 00034/04/LPPT/VII/2019).

\section{Preparation of $\mathbf{2} \%$ mangosteen peel extract}

The mangosteen peel extract was prepared, as described previously [11]. Briefly, mangosteen pericarps were sliced and dried. Then, ethanol $(1000 \mathrm{ml})$ was added to $100 \mathrm{~g}$ of the mangosteen peel slices. The solution comprising these slices was filtered and heated in a rotary vacuum evaporator at $50^{\circ} \mathrm{C}$. This solution was heated again in an oven at $90^{\circ} \mathrm{C}$ and filtered to obtain the final mangosteen peel extract. The solution was filtered with WhatMan No 1 filtered paper $(24 \mathrm{~cm})$. The filtrates were separately concentrated in vacuo using Rotary Evaporator (Model RE52A, China). The extract was stored in a refrigerator.

\section{Study period and study location}

The study was conducted from June to August 2019 at Department of Microbiology, Faculty of Veterinary Medicine, Universitas Gadjah Mada, Yogyakarta, Indonesia.

\section{Experimental design}

A total of 30 1-day-old broiler chicks (Cobb500) were divided into three groups. The chicks were kept for seven days to acclimatize. Within this period, they were fed commercial broiler starter diet only and given plain water. The number of 1-day-old chicks included in this study was calculated, according to Federer's method [12]. Group A served as the control and was not administered any treatment in the feed, Group B was administered $0.3 \mathrm{~g} / \mathrm{kg}$ colistin in the feed, and Group C was administered the prepared 2\% mangosteen peel extract in the feed. The chicks were treated for 30 days. The growth performance parameters, including body weight gain, feed intake, FCR, and the presentation of antibiotic resistance, were evaluated in the broilers. The broilers were weighed every day to measure the body weight gain. Feed intake was recorded daily by measuring the amount of feed remnants. FCR was calculated by dividing the amount of feed intake with the body weight gain. The rate of antibiotic resistance (\%) was calculated by dividing the number of bacteria that showed resistance with the total number of bacteria, as described previously $[13,14]$. The observations were recorded before (pre-treatment) and after (post-treatment) the treatments.

\section{Antibiotic sensitivity test}

Eight standard antibiotic disks for ciprofloxacin, colistin, amoxicillin, streptomycin, chloramphenicol, tetracycline, ampicillin, and gentamicin were used against the isolated bacteria after the preparation of standardized bacterial inoculums matching the 0.5 McFarland standards $(2 \times 108 \mathrm{cfu} / \mathrm{ml})$. The inoculum was spread on sterile Mueller-Hinton agar plates and incubated at $37^{\circ} \mathrm{C}$ for $24 \mathrm{~h}$. The degree of sensitivity was determined by measuring the inhibition zone diameter, as described previously $[15,16]$. The results were interpreted according to the guidelines of the Clinical and Laboratory Standards Institute [16].

\section{Statistical analysis}

The quantitative data from the different treatments in this study were statistically analyzed using analysis of variance (ANOVA), Kruskal-Wallis test, and marginal homogeneity test with $\mathrm{p}<0.05$ were considered statistically significant.

\section{Results}

\section{Body weight gain}

Table-1 summarizes the changes in the body weight in terms of body weight gain in all the groups analyzed using ANOVA. The body weight of broilers increased post-treatment, but the body weight gain in the 1st, 2nd, and 4th weeks of treatment was not significantly different among the groups $(\mathrm{p}>0.05)$. The body weight gain in Group A (control) was significantly different from that in Groups B and C (treatment groups) in the 3 rd week of treatment $(p<0.05)$. Furthermore, the body weight gain was not significantly different between Groups B and C in the 3rd week of treatment.

\section{Feed intake and FCR}

The results of the Kruskal-Wallis test showed that all the groups did not show significant differences in feed intake ( $>0.05)$, but the control and the treatment groups showed significant differences in FCR in the 3rd week $(p<0.05)($ Table-2). However, FCR was not significantly different between Groups B and C in the 3rd week of treatment.

\section{Antibiotic resistance findings}

The marginal homogeneity test showed that the broilers who were treated with colistin as an AGP (Group B) showed a significant increase in the rate 
Table-1: The effect of mangosteen peels extract on chicken body weight.

\begin{tabular}{lccc}
\hline Parameters & Group A & Group B & Group C \\
\hline Body weight & $51.90 \pm 6.12$ & $50.50 \pm 5.46$ & $47.60 \pm 4.81$ \\
Day 1 & $445.50 \pm 46.898$ & $453.80 \pm 47.138$ & $460.80 \pm 38.378$ \\
$1^{\text {st }}$ week & $719.40 \pm 68.850$ & $718.00 \pm 78.330$ & $667.20 \pm 49.620$ \\
$2^{\text {nd }}$ week & $1198.20 \pm 88.853$ & $1220.70 \pm 145.223$ & $1167.10 \pm 83.298$ \\
$3^{\text {rd }}$ week & $1389.80 \pm 109.700$ & $1393.80 \pm 212.756$ & $1401.60 \pm 153.569$ \\
$4^{\text {th }}$ week & & & \\
Body weight gain & $393.60 \pm 43.436$ & $403.30 \pm 44.535$ & $413.20 \pm 37.371$ \\
$1^{\text {st }}$ week & $273.90 \pm 31.370$ & $264.20 \pm 37.199$ & $206.40 \pm 36.127$ \\
$2^{\text {nd }}$ week & $478.80 \pm 104.303^{\text {a }}$ & $502.70 \pm 79.462^{\mathrm{b}}$ & $499.90 \pm 49.298^{\mathrm{b}}$ \\
$3^{\text {rd }}$ week & $191.60 \pm 152.030$ & $173.10 \pm 108.575$ & $234.50 \pm 184.117$ \\
$4^{\text {th }}$ week &
\end{tabular}

a,bDifferent superscript indicates significant different. Group $A=$ control, Group $B=$ given $A G P$, Group $C=$ given mangosteen peels extract $(p<0.05)$. AGP $=$ Antibiotic growth promoter

Table-2: The effect of mangosteen peels extract on feed intake and FCR.

\begin{tabular}{lccc}
\hline Parameters & Group A & Group B & Group C \\
\hline Feed intake & & & $198.80 \pm 0.0029$ \\
$1^{\text {st }}$ week & $175.80 \pm 0.0032$ & $164.20 \pm 0.0030$ & $237.06 \pm 0.0028$ \\
$2^{\text {nd }}$ week & $261.93 \pm 0.0033$ & $261.26 \pm 0.0029$ & $466.65 \pm 0.0020$ \\
$3^{\text {rd }}$ week & $466.66 \pm 0.0030$ & $466.67 \pm 0.0028$ & $786.66 \pm 0.0029$ \\
$4^{\text {th }}$ week & $786.66 \pm 0.0025$ & $786.65 \pm 0.0205$ & \\
FCR & & & $0.485 \pm 0.045$ \\
$1^{\text {st }}$ week & $0.398 \pm 0.038$ & $0.412 \pm 0.046$ & $0.357 \pm 0.026$ \\
$2^{\text {nd }}$ week & $0.366 \pm 0.033$ & $0.367 \pm 0.038$ & $0.401 \pm 0.028^{\text {b }}$ \\
$3^{\text {rd }}$ week & $1.057 \pm 0.431^{\text {a }}$ & $0.386 \pm 0.043^{\text {b }}$ & $0.554 \pm 0.059$ \\
$4^{\text {th }}$ week & $0.569 \pm 0.042$ & $0.576 \pm 0.088$ & \\
\hline
\end{tabular}

a,bDifferent superscript indicates significant different. Group $A=$ control, Group $B=$ given $A G P$, Group $C=$ given mangosteen peels extract $(p<0.05)$. FCR $=$ Feed consumption rate. AGP=Antibiotic growth promoter, $F C R=$ Feed conversion rate

of antibiotic resistance to chloramphenicol $(\mathrm{p}<0.05)$ between pre-treatment and post-treatment. However, the broilers who were treated with $2 \%$ mangosteen peel extract (Group C) did not show any increase in the rate of antibiotic resistance (Table-3).

\section{Discussion}

The present study analyzed the effects of adding mangosteen peel extract to broiler feed on body weight gain, feed intake, FCR, and the presentation of antibiotic resistance. Colistin is widely used as a growth promoter in poultry production, but with the increasing incidence of antimicrobial resistance, natural sources such as mangosteen have been explored for their potential as AGPs. We found that the control and treatment groups showed significantly different body weight gain in the 3rd week of treatment. This finding is similar to that reported by a previous study [17], wherein the use of AGPs as feed additives demonstrated improved growth and production performance in 4 weeks as well as efficiency. Antibiotics administered at subtherapeutic doses are expected to reduce the number of pathogenic microorganisms in the digestive tract to ensure that the poultry is healthy and can utilize all the nutrients in the feed, with a rapid growth rate and enhanced production efficiency [18]. In the present study, AGP didn't affected to body weight gain in the $1^{\text {st }}, 2^{\text {nd }}$, and $4^{\text {th }}$ weeks of treatment; therefore, their nutritional efficiency was considered
Table-3: Effect of mangosteen peels extract on percentage of antibiotic resistance (\%).

\begin{tabular}{lccc}
\hline Antibiotic & Group & Pre-treatment & Post-treatment \\
\hline CIP & A & 100 & 100 \\
& B & 100 & 100 \\
CT & C & 100 & 100 \\
& A & 100 & 80 \\
AML & B & 100 & 90 \\
& C & 100 & 90 \\
& A & 100 & 100 \\
C & B & 100 & 100 \\
& C & 100 & 100 \\
& A & 70 & 90 \\
S & B & $50^{\mathrm{a}}$ & $90^{\mathrm{b}}$ \\
& $\mathrm{C}$ & 100 & 80 \\
& $\mathrm{~A}$ & 100 & 100 \\
TE & $\mathrm{B}$ & 90 & 100 \\
& $\mathrm{C}$ & 100 & 100 \\
& $\mathrm{~A}$ & 100 & 100 \\
AMP & $\mathrm{B}$ & 100 & 100 \\
& $\mathrm{C}$ & 100 & 100 \\
& $\mathrm{~A}$ & 100 & 100 \\
CN & $\mathrm{B}$ & 100 & 100 \\
& $\mathrm{C}$ & 100 & 100 \\
& $\mathrm{~A}$ & 90 & 100 \\
& $\mathrm{~B}$ & 90 & 100 \\
\hline
\end{tabular}

a,bDifferent superscript indicates significant difference. Group $A=$ control, Group $B=$ given AGP, Group $C=$ given mangosteen peels extract. $\mathrm{CIP}=$ Ciprofloxacin,

$\mathrm{CT}=$ Colistin, $\mathrm{AML}=$ Amoxicilin, $\mathrm{C}=$ Cloramphenicol, $\mathrm{S}=$ Streptomycin, $\mathrm{TE}=$ Tetracycline, $\mathrm{AMP}=$ Ampicilin, $\mathrm{CN}=$ Gentamicin $(p<0.05)$. AGP=Antibiotic growth promoter 
low because of the pathogenic microorganisms that remained in the digestive tract. This finding is similar to that reported by a previous study [19] stating that antibiotic supplementation is not associated with body weight gain and microorganism types in the intestine. Therefore, the FCR in the control and treatment groups in the present study was also not found to be significantly different ( $p>0.05$ ).

The rate of antibiotic resistance to ciprofloxacin, colistin, amoxicillin, streptomycin, tetracycline, ampicillin, and gentamicin pre-treatment and post-treatment was not significantly different $(p>0.05)$ among all the groups. However, the rate of antibiotic resistance to chloramphenicol in Group B (colistin-treated group) was significantly different $(\mathrm{p}<0.05)$ from that in Groups A and C. The rate of resistance to chloramphenicol increased by $40 \%$ after the administration of colistin. This finding is consistent with that reported by a previous study [15], wherein the rate of antibiotic resistance increased by $3-70 \%$ after supplementation with additional AGPs in animal feed.

Antibiotic resistance can occur through various mechanisms such as antibiotic inactivation, membrane permeability reduction, antibiotic target modification, and antibiotic transport modification [20]. Furthermore, antibiotic inactivation can occur when microorganisms produce enzymes such as beta-lactamases that hydrolyze the beta-lactam ring, consequently inhibiting the function of beta-lactam antibiotics, for example, beta-lactamase destroys beta-lactam from penicillin, which inhibits antibiotics from adhering to the peptidoglycan of bacterial wall and eventually leads to inhibition of antibiotic function [20,21]. Changes in bacterial cell membrane permeability can occur due to genetic mutations that cause pore changes in the bacterial cell wall so that antibiotics cannot enter the bacterial cell [21]. Modification of antibiotic targets can cause antibiotic resistance because changes in the molecular structure of the antibiotic target can result in the failure of antibiotics to bind to the target, thereby making the antibiotic ineffective [22]. Another antibiotic resistance mechanism involves the removal or transportation of antibiotics such as macrolides, tetracyclines, and fluoroquinolones outside the bacterial cells, thereby making these antibiotics ineffective against bacterial infections [23].

In this study, the rate of antibiotic resistance to chloramphenicol was found to be increased in the treatment group with colistin added as an AGP. According to a previous study [24], the administration of colistin causes cross-resistance to other antimicrobials. This mechanism of cross-resistance may have caused a significant increase in the antibiotic resistance to chloramphenicol in the present study. In the present study, there was no increase in the resistance to other antibiotics because the rate of antibiotic resistance to ciprofloxacin, colistin, amoxicillin, streptomycin, tetracycline, and ampicillin in 1-day-old broiler chicks was already $100 \%$ pre-treatment and supplementation with colistin in the feed did not result in any further significant difference. However, the rate of antibiotic resistance to other antibiotics, namely, chloramphenicol and gentamicin, was $<100 \%$ pre-treatment. These results are in accordance with those reported previously by Moreno et al. [25], who showed that 1-dayold chicks exhibit varying rates of antibiotic resistance (ranging from 5\% to 75\%) to different antibiotics. A similar result has also been reported by a previous study [26], wherein E. coli isolated from 1-day-old chicks showed resistance to penicillin and ciprofloxacin. A previous study [27] has shown that the rate of antibiotic resistance in 1-day-old chicks was much higher than that in the environment. This result was supported by Okorafor et al. [28], who showed that $E$. coli isolated from 1-day-old chicks is resistant to antibiotics, including tetracycline, ampicillin, gentamicin, enrofloxacin, ciprofloxacin, and streptomycin, with rates of antibiotic resistance reaching $>80 \%$.

As stated previously [29], the presentation of antibiotic resistance in 1-day-old broiler chicks can be due to either intrinsic resistance or acquisition resistance. Intrinsic resistance is caused by genetic mutations that occur in bacterial chromosomes, whereas acquisition resistance is caused by the transfer of resistant genes from the environment or by horizontal transfer from other bacteria $[30,31]$.

\section{Conclusion}

The findings of our study suggest that compared with colistin, mangosteen peel extract used as an AGP did not have any significantly different effects on the body weight gain and FCR of broilers. However, the mangosteen peel extract significantly affected the antibiotic resistance of broilers. While the colistin-treated group showed a significant increase in the rate of antibiotic resistance to chloramphenicol post-treatment, no such increase was observed in the mangosteen peel extract-treated group, indicating significant differences in the rate of antibiotic resistance between these two groups. Therefore, mangosteen peel extract can be considered a useful natural AGP that can promote the growth and production performance of broilers without increasing the rate of antibiotic resistance.

\section{Authors' Contributions}

$\mathrm{OH}$ and $\mathrm{TU}$ designed and managed the study. $\mathrm{OH}$ and MA collected and analyzed samples. SA, OH, TU, and MA arranged, analyzed, and wrote the manuscript. All authors have read and approved the final manuscript.

\section{Acknowledgments}

The study was funded by Universitas Gadjah Mada, Indonesia with an assignment letter no 3904/ UNI/DITLIT/DIT-LIT/LT/2019.

\section{Competing Interests}

The authors declare that they have no competing interests. 


\section{Publisher's Note}

Veterinary World remains neutral with regard to jurisdictional claims in published institutional affiliation.

\section{References}

1. Watson, R. (2008) Multidrug resistance responsible for half of deaths from healthcare associated infections in Europe. BMJ, 336(7656): 1266-1267.

2. Li, B. and Webster, T.J. (2018) Bacteria antibiotic resistance: New challenges and opportunities for implant-associated orthopedic infections. J. Orthop. Res., 36(1): 22-32.

3. Hadi, U., Kuntaman, K., Qiptiyah, M. and Paraton, H. (2013) Problem of antibiotic use and antimicrobial resistance in Indonesia: Are we really making progress? IJTID, 4(4): 5-8.

4. Michael, C.A., Howes, D.D. and Labbate, M. (2014) The antimicrobial resistance crisis: Causes, consequences, and management. Front. Public Health, 2(145): 1-8.

5. Barton, M.D. (2000) Antibiotic use in animal feed and its impact on human health. Nutr. Res. Rev., 13(2): 279-299.

6. Boeckela, T.P.V., Browerb, C., Gilbertc, M., Grenfella, B.T., Levina, S.A., Robinsoni, T.P., Teillanta, A. and Laxminarayan, R. (2015) Global trends in antimicrobial use in food animals. PNAS, 112(18): 5649-5654.

7. Manimekalai, I., Sivakumari, K., Ashok, K. and Rajesh, S. (2016) Phytochemical profiling of mangosteen fruit, Garcinia mangostana. WJPPS, 5(2): 221-252.

8. Jamila, N., Khan, N., Khan, A.A., Khan, S.N. and Kim, K.S (2016) Phytochemical analysis, antioxidant, anti-hyperglycemic and antituberculosis activities of phylogenetically related Garcinia mangostana (mangosteen) and Garcinia hombroniana (seashore mangosteen). J. Chem. Soc. Pak., 38(6): 1181-1189.

9. Janardhan, S., Mahendra, J., Girija, A.S.S., Mahendra, L. and Priyadharsini, V. (2017) Antimicrobial effects of Garcinia mangostana on cariogenic microorganisms. J. Clin. Diag. Res., 11(1): 19-22.

10. Hidanah, S., Warsito, S.H., Nurhajati, T., Lokapirnasari, W.P. and Malik, A. (2016) Effects of mangosteen peel (Garcinia mangostana) and ginger rhizome (Curcuma xanthorrhiza) on the performance and cholesterol levels of heat-stressed broiler chickens. Pak. J. Nutr., 16(1): 28-32.

11. Trihadi, B. and Triawan, D.A. (2016) Penggunaan ekstrak kulit manggis hasil ekstraksi alkohol untuk pengawetan telur. Jurnal Gradien, 12(2): 1209-1214.

12. Federer, W.T. (1967) Experimental Design, Theory and Application. Oxford and IBH Publishing. Co., New Delhi.

13. Kusmayadi, A., Bachtiar, K.R. and Prayitno, C.H. (2019) The effects of mangosteen peel (Garcinia mangostana L.) and turmeric (Curcuma domestica Val) flour dietary supplementation on the growth performance, lipid profile and abdominal fat content in Cihateup ducks. Vet. World, 12(3): 402-408

14. Al-Gheethi, A.A.S., Molhit, A., David, J.B., Efaq, A.N. and Ismail, N. (2005) Prevalence of antimicrobial resistance Bacteria in non-clinical environment. Proc. ICERT, 4 (5): 443-449.

15. Beleguer, A.J., Domence, E., Villagra, A., Fenolar, A. and Ferrus, M.A. (2016) Antimicrobial resistance of Escherichia coli isolated in newly-hatched chickens and effect of amoxicillin treatment during their growth. Avian. Pathol., 45(4): 501-507.
16. CLSI. (2011) Performance Standards for Antimicrobial Disk Susceptibility Tests; Approved Standards. $11^{\text {th }}$ ed. CLSI, Wayne, PA.

17. Ramli, N., Suci, D.M., Sunanto, S., Nugraheni, C., Yulifah, A. and Sofyan, A. (2008) Performan ayam broiler yang diberi ransum mengandung potasium diformate sebagai pengganti flavomycin. Agripet, 8(1): 1-8.

18. Sinurat, A.P., Purwadaria, T., Togatorop, M.H. and Pasaribu, T. (2003) Pemanfaatan bioaktif tanaman sebagai "feed additive" pada ternak unggas: Pengaruh pemberian gel lidah buaya atau ekstraknya dalam ransum terhadap penampilan ayam pedaging. JITV, 8(3): 139-145.

19. Kumar, S., Chen, C., Indugu, N., Werlang, G.O., Singh, M., Kim, W.K. and Thippareddi, H. (2018) Effect of antibiotic withdrawal in feed on chicken gut microbial dynamics, immunity, growth performance and prevalence of foodborne pathogens. PLoS One, 13(2): 1-23.

20. Dugassa, J. and Shukuri, N. (2017) Review on antibiotic resistance and its mechanism of development. JHMN, 1(3): $1-17$

21. Galdiero, S., Falanga, A., Cantisani, M., Tarallo, R., Pepa, M., D'Oriano, V. and Galdiero, M. (2012) Microbe host interactions: Structure and role of gram-negative bacterial porins. Curr. Protein. Pept. Sci., 13(8): 843-854.

22. Denyer, S.P., Hodges, N.A., Gorman, S.P. and Gilmore, B.F. (2011) Hugo and Russell's Pharmaceutical Microbiology. $8^{\text {th }}$ ed. Wiley Blackwell Publishing House, India, NewDelhi.

23. Willey, J.M., Sherwood, L.M. and Woolverton, C.J. (2013) Prescott's Microbiology. $9^{\text {th }}$ ed. McGraw-Hill, New York.

24. Napier, B.A., Burd, E.M., Satola, S.W., Cagle, S.M., Ray, S.M., McGann, P., Pohl, J., Lesho, E.P. and Weiss, D.S. (2013) Clinical use of colistin induces cross-resistance to host antimicrobials in Acinetobacter baumannii. mBio, 4(3): e00021-13.

25. Moreno, M.A., Sotoa, S.G., Hernandez, M., Barcenaa, C., Lazarod, D.R., Ruiza, M.U. and Domingueza, L. (2019) Day-old chicks are a source of antimicrobial-resistant Bacteria for laying hen Farms. Vet. Microbiol., 230(5): 221-227.

26. Anyanwu, A., Fasina, F., Ajayi, O.T., Rapu, I. and Fasina, M.M. (2010) Antibiotic-resistant Salmonella and Escherichia coli isolated from day-old chicks, Vom, Nigeria. Afr. J. Clin. Exp. Microbiol., 11(1): 51-57.

27. Osman, K.M., Kappell, A.D., Elhadidy, M., Elmougy, F., El-Ghany, W.A.A., Orabi, A., Mubarak, A.S., Dawoud, T.M., Hemeg, H.A., Moussa, I.M.I., Hessain, A.M. and Yousef, H.M.Y. (2018) Poultry hatcheries as potential reservoirs for antimicrobial-resistant Escherichia coli: A risk to public health and food safety. Nature, 8 (5859):1-14.

28. Okorafor, O.N., Anyanwu, M.U., Nwafor, E.O., Anosa, G.N. and Udegbunam, R.I. (2019) Multidrug-resistant enterobacteria colonize commercial day-old broiler chicks in Nigeria. Vet. World, 12(3): 418-423.

29. Davies, J. (2007) Microbes have the last word. EMBO Rep., 8(7): 616-621.

30. McDermott, P.F, Walker, R.D. and White, D.G. (2003) Antimicrobials: Modes of action and mechanisms of resistance. Int. J. Toxicol., 22(2): 135-143.

31. Randall, L.P., Cooles, S.W., Osborn, M.K., Piddock, L.J.V. and Woodward, M.J. (2004) Antibiotic resistance genes, integrons and multiple antibiotic resistance in thirty-five serotypes of Salmonella enterica isolated from humans and animals in the UK. J. Antimicrob. Chemother., 53(2): 208-216. 